\title{
Centrism, 'expertise' and the 2019 UK General Election: a review of Nervous States: How Feeling Took Over the World
}

\author{
Elliott Johnson ${ }^{1}$
}

This is an Author's Original Manuscript (AOM) of an article published by Bristol University Press in Global Discourse in May 2020, available online:

https://doi.org/10.1332/204378920X15810107885597.

Nervous States: How Feeling Took Over the World by William Davies, London, Vintage, 2019, 272 pp., $£ 9.99$ (paperback), ISBN: 9781784707033

Key words: centrism; 2019 UK general election; Jeremy Corbyn; fake news; post-truth

In Nervous States, William Davies' engages with historical developments that have resulted in a contemporary sociopolitical environment shared by many nations. This consists in a state of heightened 'feeling' and competition driven by the anticipation of threat and violence in an environment in which the gap between war and peace has been eroded. This results in a quagmire in which truth is the narrative that competes most effectively, ownership of information - or 'intelligence' - is taken into the hands of a few individuals and 'feeling' drives the political agenda.

Davies dedicates a substantial portion of the book, and admiration, to the development of peaceful society and the scientific method in the $17^{\text {th }}$ Century. He also acknowledges the 'necessarily' slow pace of the pursuit of representing objective truth, the role this gave a small elite of experts and its focus - in the social arena - on national statistics that held little place for individual experience, particularly pain (60). These features are used against experts by populists who promise immediate transformation $(203,221)$, escape from pain $(224)$ and not just the incremental gains of the 'progressive' technocrat (214).

As Davies' writes:

For someone who has had no pay rise for forty years, or has a job that is lower status than his father's was, this narrative has a credibility that no quantity of facts and figures can acquire. For this person, appeals to statistical objectivity - with the emphasis on averages and aggregation that that implies - can add insult to injury. (pp.87-88)

He further highlights that from 2010-15, London median household wealth rose by $14 \%$ but fell by $8 \%$ in Yorkshire and the Humber while the UK is the fifth largest economy in the world but a majority of its regions have GDP below European average (77). In other words, even lacking-in-individualexperience statistics show gains have benefitted a narrow group.

It is difficult to imagine a clearer demonstration of the culmination of this ignorance of individual 'injury' and belief in averages than the 2019 UK General Election. In the election, a party responsible for much of this individual injury through almost a decade of austerity policy - the Conservatives shaped a simple message that appealed to the identity of those they had attacked: Get Brexit Done.

Davies references behavioural economic experiments that show

\footnotetext{
${ }^{1}$ Independent Research Consultant. ORCID ID: 0000-0002-0937-6894. ejohnsonresearch@gmail.com
} 
all else being equal, people place greater value on not losing that which they already have, than on gaining something of equivalent value. As behavioural economists would say, we are fundamentally 'loss-averse' creatures. Where victory is enjoyed and then quickly taken for granted, the experience of loss shapes our identity, forging a melancholic sense of nostalgia. (145)

He is right that appeals to what has been lost are important. However, there is another issue at play here. Populists in the UK, particularly Nigel Farage, do reference loss of national identity and community cohesion. But their rhetoric is not negative, at least for those who share the feeling of loss. As Davies notes, Farage was faced with derision for claiming that

To have fewer happier people enjoying a better quality of life, keeping their identity, being happy with who they are and living in communities at ease with themselves where their kids can go and play football in the street is far more important than an increase in GDP. (Hope 2015)

He claimed in another interview that the social side of united communities and youth employment over migration and national wealth 'matters more than pure market economics' (Holehouse 2014).

While ironic for someone who identifies as a libertarian, the power of his words stems not from their being divisive, but from their offering a positive vision for the future. At the same time, future Liberal Democrat leader Vince Cable, then Business Secretary in the Coalition Government, argued against lower net migration targets because, due to EU membership, 'it's not sensible to have an arbitrary cap because most of the things under it can't be controlled' (Holehouse 2014). In a context in which GDP had been rendered largely irrelevant to many people's lives, progressives were either arguing for migration and EU membership because of a notional benefit to an irrelevant statistic or against cutting migration because an institution that opponents sought to leave made it impossible. It's not difficult to see how these arguments were lost.

In the 2019 General Election, the political 'Centre' - who considered themselves to have statistical truth on their side - told Leave voters that they were ignorant, racist and self-defeating (see Mckenzie 2018). The reasoning was wholly negative: a negative view of the past, and only a 'lessnegative' view of the optimal future. Meanwhile, a negative effect from migration on salaries of the lowest paid was glossed over as insignificant (Reality Check team 2019), when avoiding forecast Brexit-related reductions in GDP growth of a similar order were the basis for the Liberal Democrat Manifesto (BBC News 2019). A merging of technocracy, careerism and the political Centre sum up the last few years of Western politics. Centrists' belief that they own facts has done as much to muddy 'truth' as has the rise of right-wing populists. Right-wing populists have just shown themselves to be more effective at narrative-building.

Davies, perhaps in seeking 'balance', makes a common but foundationless error in associating - at least by textual proximity - Jeremy Corbyn with Donald Trump as a populist $(65,80,197)$. Davies' thesis is that (primarily right-wing) libertarians - beginning with Ludwig von Mises, through Friedrich Hayek and to modern billionaire 'Founders' like Peter Thiel - have succeeded in eroding belief in truth and experts in favour of fast-paced 'intelligence' with an objective only to have the most successful narrative (150-175). Whatever else he may be, Corbyn is the very antithesis to that movement. He is sharply criticised for his Marxism (Finkelstein 2019), his unwillingness to adapt to the ever-changing political environment, his perceived 'weakness' (Toynbee 2019) and his 
'indecisiveness' (Foster 2019). He was denounced for being a closet Brexiteer (Umunna 2019), a Remainer (Doyle 2019) and for being neutral (Flint 2019). These are not coherent lines of attack based on 'facts'. Indeed, Corbyn is regarded by others, positively (Bennett 2016) or negatively (Johnston 2017), as remarkably consistent in his views. He did not, when elected, become the PRsavvy, 'strategic' career politician focused on making political capital in order to increase his 'electability'. This is what baffled and outraged the previous Centrist leadership of the party (McNicol 2020).

So why is Corbyn so criticised for lacking credibility? Davies outlines how experts and politicians became so closely entwined that the language of expertise became one of couching moral arguments in the language of 'evidence' and 'what works' (53). He also highlights how quickly technocrats went from evidence-based policy to policy-based evidence (58). Centrists have become specialists in this. In 2009, Professor David Nutt, chair of the Advisory Committee on the Misuse of Drugs, was sacked by then Home Secretary, Alan Johnson, after he accused ministers of 'devaluing and distorting' scientific evidence in ignoring the advice of the Committee and increasing the penalties associated with cannabis possession (Travis 2009). Johnson argued Nutt could not 'be both a government adviser and a campaigner against government policy' (Johnson 2009). This incident revealed confirmation bias as inherent in the New Labour Government's approach to policy: where evidence supported their agenda, it was trailed for public relations purposes; where evidence called for politically-unpalatable options, they looked for 'alternative' evidence and dismissed those who disagreed. The 2019 election demonstrated just how effective, but self-defeating, this alignment between experts and the Centrist establishment has become.

Davies believes that this erosion of trust in experts has been accelerated by the internet. He highlights its development from a military basis, which no doubt chimes with contemporary 'feelings' about elections and referenda over the last five or so years. He writes that real-time media means 'that we spend more of our time immersed in a stream of images and sensations, with less time for reflection or dispassionate analysis' (184).

There is in this, however, an undue trust placed in the past and the role that traditional media played in representing the world 'unpolluted by personal feelings or bias' (203). While UK broadcast media are regulated, this does not necessarily eliminate bias (Lewis and Cushion 2019). Alongside this, almost all UK newspapers take political stances, with a substantial majority backing the Conservatives (Taylor 2018). Indeed, Cammaerts et al. (2016) found that the press had unfairly delegitimised Corbyn as early as his emergence as a leading figure in 2015 , while hostility increased dramatically during the 2019 General Election (Deacon et al. 2019). The whole debate around bias, however, is not aided by a framing of bias as a left/right dichotomy (Smith 2017). Centrism is not equivalent to independence and expertise: Centrists take economic and social positions just as clearly as those on the ends of the political spectrum.

Putting the role of 'traditional' journalism to one side, Davies' argument also ignores dynamics at play in countries like the UK. Office for National Statistics (2019) data show that $98 \%$ of 16- to 24year-olds used the internet for social media compared to $52 \%$ of 55 - to 64 -year-olds and $31 \%$ of those aged $65+$. And in terms of online news, the figures are $84 \%$ for 16 - to 24 -year-olds, $58 \%$ for 55 to 64 -year-olds and $37 \%$ for those aged $65+$. But the groups driving the UK policy agenda are not the internet-obsessed Millennials or Generation Z, but the Baby Boomers and above (aged 55+) through their large numbers and high voter turnout. 
Research by Ipsos MORI (2019) showed that in the 2019 General Election, Labour held a $43-$ percentage-point lead among voters aged $18-24$ but at a turnout of just $47 \%$. Meanwhile, the Conservatives held a 47 -point lead among those aged $65+$ with a turnout of $74 \%$. While the swing away from Labour was highest among 35- to 54-year-olds, Baby Boomers give the Conservatives an in-built and almost insurmountable advantage.

High turnout is no surprise, since Baby Boomers have seen their interests served by participating. Although age groupings in data make it a relatively rough estimate, 2005 appears to be the only General Election since comparable Ipsos MORI data began in 1974 in which Baby Boomers may not necessarily have got their way (Ipsos MORI 2010, 2015, 2017, 2019). That is an astonishing domination of politics by one age group. The fact that the difference between preferences of the youngest and oldest age groups is getting greater can only serve to build a sense of frustration among young Millennials and Generation Z.

So if older groups are still driving the political agenda, what is driving their 'feelings'? According to 2019 Ofcom figures on news consumption (Ofcom and Jigsaw Research 2019), 83\% of 16- to 24-yearolds get their news via the internet compared to just $40 \%$ of those aged $65+$. Meanwhile almost twice as many of those aged $65+$ use television (94\% vs $51 \%$ ) or the radio ( $49 \%$ vs 26 ) and three times more likely to use printed newspapers ( $58 \%$ vs $20 \%$ ). On the other hand, 16 - to 24 -year-olds are more than three times as likely to use social media posts ( $56 \%$ vs $17 \%$ ).

It is likely that media influences the political climate, but the evidence indicates that it is not just an online phenomenon. It is not those that are most engaged with the 'military-like' media of the internet, but the 'expert-mediated' sources Davies appears to laud. It seems that it is those who developed in the peaceful post-war era that are the leading edge of reactionary and 'war-like' behaviour and attitudes. Indeed, those from those age groups that do become exposed to misleading social media content directly or indirectly via the traditional media are much less capable of differentiating real and fake news. A recent US study showed that those aged 65+ 'shared nearly seven times as many articles from fake news domains as the youngest age group' on Facebook (Guess, Nagler and Tucker 2019, 4-5). The authors suggest a lack of digital literacy skills may be the cause, or that this group see social endorsements as 'credibility cues'. The reasons for a generation that received unparalleled social, economic and political support's finding difficulty in differentiating fact from fiction are unclear.

Nevertheless, a narrative describing Corbyn's Millennial and Generation Z supporters as an idealistic, unrealistic online cult continues (Stanley 2018; Turner 2019). Davies criticises online culture more broadly as involving 'gleeful nihilism', in which only the outcome matters and all dialogue particularly via memes and trolling - is strategic and a game of causing offence (193-4). The evidence, though, is that young people - the internet-obsessed generation - are more likely to be concerned about real-world harms like climate change. The British Social Attitudes Survey 35 (Phillips et al. 2018), found that ' $31 \%$ of $18-34$ year olds are "very" or "extremely" worried about climate change compared with just $19 \%$ of over-65s.' In fact, the general crisis of trust in experts at the core of Davies' argument is not necessarily borne out by the public attitudes as a whole. In 2019, $85 \%$ of the public said they trust university scientists to work with the intention of benefitting the public, compared with $67 \%$ for commercial scientists (Curtice et al. 2019, 46), perhaps indicating an awareness of concerns Davies raises about privatisation of 'intelligence'. Meanwhile, the proportion 
of UK respondents who feel that we place too much emphasis on science over feelings and faith has reduced markedly since 2000 (Curtice et al. 2019, 59).

As such, trust in science seems high and young people - with lower influence over policy - care about the real world more than previous generations while also being heavily engaged in the technological systems of 'feeling' that Davies instinctively rejects. So why does Nervous States 'feel' like a reasonable representation of the current environment? Could it be that older generations particularly in the 'Centre' - have been so effective in co-opting 'expertise' for their agenda that their 'truth' obscures the moderate, progressive nature of younger generations who have far more in common with the post-war consensus than the last 40 years of neoliberalism that their parents and grandparents have endorsed?

Centrist leaders, like Tony Blair, mount arguments with an authority that belies a selective use of evidence. For example, following the 2019 election, Blair (2019) claimed that the 'biggest percentage fall in Labour voters between 2017 and 2019 was amongst young people, probably dismayed by the ambiguity over a Brexit they detested.' In reality, the proportion of the 18-24 vote remained the same for Labour (62\%) and actually fell by eight points for the Conservatives (Ipsos MORI 2019). The overall turnout among that group was, though, down by eight points. To argue that a historic high in support could have been bolstered in a subsequent election to the point of being anywhere near winning is fanciful. In fact, Ipsos MORI 2017 and 2019 data indicates that while 13\% of the 2017 Labour Remain vote went to the Lib Dems and others, 23\% of the 2017 Labour Leave vote went to the Conservatives. That latter shift was absolutely crucial in determining the outcome in the Labour heartlands. That was in a scenario in which Labour had settled on a policy that clearly favoured a more Remain outcome: a second referendum with a Soft Brexit vs Remain on the ballot. In fact, this is the position that Centrists, including Tony Blair, had demanded (Helm 2018).

Davies argues that

Existing centres of elite power must now open their world view to understanding some of the processes that they've dismissed as 'irrational' or 'post-truth', and to throw their considerable influence behind a different social and economic settlement. (223-4)

To do this, these centres of elite power would need to acknowledge that they are significant exponents of 'post-truth' narratives - to the extent that they seem to believe that the subjective narratives they create are objective truth. And this is not restricted to the UK. In the US, Centrists continue to propose Joe Biden as Democrat presidential candidate on the basis of his 'electability' (Green 2019), despite previous 'electable' candidates, such as Hillary Clinton in 2016, having failed disastrously. The data is not there to defend such assertion.

Davies is surely correct in arguing that right-wing libertarians tend not to be concerned about objective truth. But it is not younger people supporting this agenda: they are rejecting an establishment complicit in that 'electability' above 'truth' agenda. Davies suggests that scientists and experts become more active in campaigning and strategic in achieving their goals. Backing pro-EU Centrists like Jo Swinson's Liberal Democrats - whose 'win at all costs' mentality in the 2019 election included production of misleading leaflets ( $\mathrm{O}^{\prime}$ Carroll 2019) and proved less than electable - is unlikely to reinvigorate an expertise-led society. 
Also unlikely to support this revival is a commitment to paradigms that have been falsified empirically. Homo economicus, the perfectly 'rational' theoretical individual on whom neoliberal theory is based, has been debunked through behavioural economics. In ultimatum games, one participant is granted a sum of money and instructed to offer a proportion of that amount to a recipient. The recipient must accept the offer in order for either to keep the money. Contra homo economicus, sums even approaching half have been rejected on the basis that they are perceived as unfair (Henrich and Smith 2004, 142-143; Gil-White 2004, 272). A homo economicus recipient would accept any sum, because it is 'irrational' to reject something that would make them objectively better off. 'Experts' who fail to reconsider a falsified paradigm are no longer experts.

Davies is correct in saying that phoney science can be demolished even if it often takes too long to do so when faced with projects of mobilisation of public sentiment that are unconcerned with representation (165). This is Karl Popper's science as falsification. But the irony is that in the case of neoliberal economics, pioneered by Popper's associates Mises, Hayek and Milton Friedman, experts were able to set their own criteria for success. Centrists similarly, and unfalsifiably, set their own criteria for success and failure during Corbyn's tenure as leader. Corbyn's strategy in the 2017 General Election - including a commitment to delivering on Brexit - resulted in the largest increase in vote share for a party since 1945, including Blair's landslide in 1997 (Lukas, Cracknell and Loft 2019). A significant statistical achievement, but a failure for Centrists (Phillipson 2017).

In the 2019 General Election, only the right-wing populism of Boris Johnson was promising to deliver on a national referendum. Without all the 'feeling' surrounding Brexit, this would be considered as not only the right but also the obvious course of action within a democracy. Having spent three years finding dubious reasons to reject the Referendum on EU Membership, there have been few attempts to reject the outcome of the 2019 General Election, despite its being a far less fair representation of public opinion: The Conservatives currently have $56 \%$ of seats in the House of Commons on a vote share of $43.6 \%$ (Uberoi 2020, 6). Corbyn was not afforded the opportunity to simply Get Brexit Done (see Conservative and Unionist Party 2019) due to the strong 'feeling' among his MPs. Unlike Johnson, he did not simply purge dissenters, who made up a larger proportion of his MPs than Johnson's. Ironically, he sought a 'Third Way'.

Evidence thrown up by the 2019 UK General Election suggests that Davies needs to add an addendum to his thesis that some experts have overlooked individual experience and populists have exploited that: some experts are not actually experts, but merely (often unpopular) populists in disguise.

\section{Bibliography}

BBC News (2019) 'Lib Dems vow f50bn "windfall” from stopping Brexit', 20 November. Available at: https://www.bbc.com/news/election-2019-50486538 (Accessed: 1 February 2020).

Bennett, R. (2016) 'Jeremy Corbyn has been on the right side of history for 30 years. That's real leadership', The Guardian, 16 September. Available at:

https://www.theguardian.com/commentisfree/2016/sep/16/jeremy-corbyn-leadership-davidcameron-libya-labour (Accessed: 1 February 2020).

Blair, T. (2019) 'Tony Blair's speech on the future of Labour and progressive politics: full text', New Statesman, 18 December. Available at: 
https://www.newstatesman.com/politics/uk/2019/12/tony-blair-s-speech-future-labour-andprogressive-politics-full-text (Accessed: 2 February 2020).

Cammaerts,B., DeCillia, B., Magalhães, J. and Jimenez-Martínez, C. (2016) Journalistic Representations of Jeremy Corbyn in the British Press: From Watchdog to Attack Dog. Available at: https://www.Ise.ac.uk/media-and-communications/research/researchprojects/representations-of-jeremy-corbyn.aspx (Accessed: 4 February 2020).

Conservative and Unionist Party (2019) Get Brexit Done, Unleash Britain's Potential: The Conservative and Unionist Party Manifesto 2019. Available at: https://assets-global.websitefiles.com/5da42e2cae7ebd3f8bde353c/5dda924905da587992a064ba Conservative\%202019\% 20Manifesto.pdf (Accessed: 2 February 2020).

Curtice, J., Clery, E., Perry, J., Phillips M. and Rahim, N. (eds) (2019) British Social Attitudes: The 36th Report, London: The National Centre for Social Research. Available at: https://www.bsa.natcen.ac.uk/downloads/bsa-36-downloads (Accessed: 28 January 2020).

Deacon, D., Goode, J., Smith, D., Wring, D., Downey, J. and Vaccari, C. (2019) General Election 2019 media reporting, report 5: $7 \mathrm{Nov}$ - 11 Dec. Available at: https://www.lboro.ac.uk/newsevents/general-election/report-5 (Accessed: 4 February 2020).

Doyle, J. (2019) 'Boris Johnson will lay into Jeremy Corbyn over leaving the EU', Mail Online. Available at: https://www.dailymail.co.uk/news/article-7770213/Boris-Johnson-lay-JeremyCorbyn-leaving-EU.html (Accessed: 1 February 2020).

Finkelstein, D. (2019) 'Corbyn's circle still lament end of Soviet rule', The Times, 5 March. Available at: https://www.thetimes.co.uk/article/corbyn-s-circle-still-sorry-the-soviet-union-felljhh60sszt (Accessed: 1 February 2020).

Flint, C. (2019) 'Corbyn's failed Brexit strategy sealed Labour's fate', The Guardian, 15 December. Available at: https://www.theguardian.com/commentisfree/2019/dec/15/jeremy-corbynbrexit-labour-working-class (Accessed: 1 February 2020).

Foster, P. (2019) 'Why is Jeremy Corbyn so unpopular?', The Telegraph, 25 November. Available at: https://www.telegraph.co.uk/politics/0/why-jeremy-corbyn-unpopular-polls/ (Accessed: 1 February 2020).

Gil-White, F. J. (2004) 'Ultimatum Game with an Ethnicity Manipulation: Results from Khovdiin Bulgan Sum, Mongolia', in J. Henrich, R. Boyd, S. Bowles, C. Camerer, E. Fehr, \& H. Gintis (eds), Foundations of Human Sociality: Economic experiments and ethnographic evidence from fifteen small-scale societies, Oxford: Oxford University Press, pp 260-304.

Green, L. (2019) 'Why is Joe Biden leading the polls? Because electability is a real thing', The Guardian, 12 September. Available at:

https://www.theguardian.com/commentisfree/2019/sep/12/joe-biden-2020-race-anti-trump (Accessed: 2 February 2020).

Guess, A., Nagler, J. and Tucker, J. (2019) 'Less than you think: Prevalence and predictors of fake news dissemination on Facebook', Science Advances, 5 (1): eaau4586. doi:

10.1126/sciadv.aau4586. 
Helm, T. (2018) 'Tony Blair urges MPs to vote down any Brexit deal and push for people's vote', The Observer, 4 November. Available at:

https://www.theguardian.com/politics/2018/nov/04/tony-blair-urges-mps-vote-down-theresamay-brexit-deal (Accessed: 2 February 2020).

Henrich, J. and Smith, N. (2004) 'Comparative experimental evidence from Maciguenga, Mapuche, Huinca, and American populations', in J. Henrich, R. Boyd, S. Bowles, C. Camerer, E. Fehr, \& H. Gintis (eds), Foundations of Human Sociality: Economic experiments and ethnographic evidence from fifteen small-scale societies, Oxford: Oxford University Press, pp 125-167.

Holehouse, M. (2014) I'd rather be poorer with fewer migrants, Farage says, The Telegraph, 7 January. Available at: https://www.telegraph.co.uk/news/uknews/immigration/10555158/ldrather-be-poorer-with-fewer-migrants-Farage-says.html (Accessed: 30 January 2020).

Hope, C. (2015) 'Nigel Farage says Ukip's popularity is falling', The Telegraph, 2 April. Available at: https://www.telegraph.co.uk/news/politics/nigel-farage/11511515/Nigel-Farage-says-Ukipspopularity-is-falling.html (Accessed: 30 January 2020).

Ipsos MORI (2010) How Britain Voted Since October 1974, Available at:

https://www.ipsos.com/ipsos-mori/en-uk/how-britain-voted-october-1974 (Accessed: 30 January 2020).

Ipsos MORI (2015) How Britain voted in 2015, Available at: https://www.ipsos.com/ipsos-mori/enuk/how-britain-voted-2015 (Accessed: 30 January 2020).

Ipsos MORI (2017) How Britain voted in 2017, Available at: https://www.ipsos.com/ipsos-mori/enuk/how-britain-voted-2017-election (Accessed: 30 January 2020).

Ipsos MORI (2019) How the voters voted in the 2019 election. Available at:

https://www.ipsos.com/ipsos-mori/en-uk/how-britain-voted-2019-election (Accessed 28 January 2020).

Johnson, A. (2009) 'Letters: Why Professor David Nutt was shown the door', The Guardian, 2 November. Available at: https://www.theguardian.com/politics/2009/nov/02/drug-policy-alanjohnson-nutt (Accessed: 28 January 2020).

Johnston, P. (2017) 'Yes, Jeremy Corbyn is a consistent politician - he's been consistently wrong for 40 years', The Telegraph, 7 June. Available at:

https://www.telegraph.co.uk/news/2017/06/07/yes-jeremy-corbyn-consistent-politicianconsistently-wrong (Accessed: 1 February 2020).

Lewis, J. and Cushion, S. (2019) 'Think Tanks, Television News and Impartiality: The ideological balance of sources in BBC programming', Journalism Studies, 20 (4): 480-499. doi: $\underline{10.1080 / 1461670 X .2017 .1389295}$.

Lukas, A., Cracknell, R. and Loft, P. (2019) UK Election Statistics: 1918-2019: A Century of Elections Supporting Documents, Download 7529, Table 1a. Available at https://researchbriefings.parliament.uk/ResearchBriefing/Summary/CBP-7529 (Accessed: 2 February 2020). 
Mckenzie, L. (2018) 'We don't exist to them, do we?': why working-class people voted for Brexit. Available at: https://blogs.Ise.ac.uk/brexit/2018/01/15/we-dont-exist-to-them-do-we-whyworking-class-people-voted-for-brexit (Accessed: 30 January 2020).

McNicol, I. (2020) 'Corbynism must end with Corbyn', Financial Times, 11 January. Available at: https://www.ft.com/content/d452464e-3398-11ea-a329-0bcf87a328f2 (Accessed: 1 February 2020).

O'Carroll, L. (2019) 'Lib Dems criticised for selective use of polling data on leaflets' The Guardian, 16 November. Available at: https://www.theguardian.com/politics/2019/nov/16/lib-demscriticised-for-selective-use-of-polling-data-on-leaflets (Accessed: 2 February 2020).

Ofcom and Jigsaw Research (2019) News consumption in the UK:2019, Available at: https://www.ofcom.org.uk/research-and-data/tv-radio-and-on-demand/news-media/newsconsumption (Accessed: 30 January 2020).

Office for National Statistics (2019) Internet access - households and individuals, 2019, Table 10. Available at: https://bit.ly/36ZXNfd (Accessed 28 January 2020).

Phillips, D., Curtice, J., Phillips, M. and Perry, J. (eds.) (2018) British Social Attitudes: The 35th Report, London: The National Centre for Social Research. Available at:

https://www.bsa.natcen.ac.uk/downloads/bsa-35-downloads (Accessed: 29 January 2020).

Phillipson, B. (2017) 'The 2017 election was far from a triumph - Labour must do a lot more to win', The New Statesman, 12 September. Available at:

https://www.newstatesman.com/politics/uk/2017/09/2017-election-was-far-triumph-labourmust-do-lot-more-win (Accessed: 3 February 2020).

Reality Check team (2019) 'Reality Check: Has immigration held down wages?', BBC News, 18 January. Available at: https://www.bbc.com/news/business-46918729 (Accessed: 30 January 2020).

Smith, M. (2017) How left or right-wing are the UK's newspapers?. Available at: https://yougov.co.uk/topics/politics/articles-reports/2017/03/07/how-left-or-right-wing-areuks-newspapers (Accessed: 3 February 2020).

Stanley, T. (2018) 'Corbynism has become a weird, ugly cult, and the saddest thing is that it's Labour that's losing out', The Telegraph, 7 August. Available at:

https://www.telegraph.co.uk/politics/2018/08/07/corbynism-has-become-cult-saddest-thinglabour-losing (Accessed: 3 February 2020).

Taylor, R. (2018) How well does the UK's media system support democratic politics and represent citizens' interests?. Available at: https://www.democraticaudit.com/2018/08/30/2018audithow-well-does-the-uks-media-system-support-democratic-politics-and-represent-citizensinterests/ (Accessed: 4 February 2020).

Toynbee, P. (2019) 'Jeremy Corbyn's weak leadership betrays those Labour would lift from poverty', The Guardian, 18 July. Available at:

https://www.theguardian.com/commentisfree/2019/jul/18/ieremy-corbyn-weak-leadershiplabour-poverty-john-mcdonnell (Accessed: 1 February 2020). 
Travis, A. (2009) 'Chief drug adviser David Nutt sacked over cannabis stance', The Guardian, 30 October. Available at: https://www.theguardian.com/politics/2009/oct/30/david-nutt-drugsadviser-sacked (Accessed: 28 January 2020).

Turner, J. (2019) 'Sorry, kids, but I can't vote for Corbyn's cult', The Times, 30 November. Available at: https://www.thetimes.co.uk/article/sorry-kids-but-i-cant-vote-for-corbyns-cult-3d7wragsz (Accessed: 3 February 2020).

Uberoi, E., Baker, C., Cracknell, R., Allen, G., Roberts, N., Barton, C., Sturge, G., Danechi, S., Harker, R., Bolton, P., Mclnnes, R., Watson, C., Dempsey, N. and Audickas, L. (2020) General Election 2019: results and analysis. Available at:

https://researchbriefings.parliament.uk/ResearchBriefing/Summary/CBP-8749 (Accessed: 2 February 2020).

Umunna, C. (2019) Jeremy Corbyn is and always was a Brexiteer, The Independent. Available at: https://www.independent.co.uk/voices/ieremy-corbyn-brexit-chuka-umunna-theindependent-group-leave-remain-a8828001.html (Accessed: 1 February 2020). 